\title{
Consumer behavior and knowledge on organic vegetables in Cyprus
}

\author{
${ }^{1}$ Chrysargyris, A., ${ }^{1}$ Xylia, P., ${ }^{1}$ Kontos, Y., ${ }^{2}$ Ntoulaptsi, M. and ${ }^{1 *}$ Tzortzakis, N. \\ ${ }^{I}$ Cyprus University of Technology, Department of Agricultural Sciences, \\ Biotechnology and Food Science, 3036, Limassol, Cyprus \\ ${ }^{2}$ Ministry of Education, Research and Religious Affairs, 11527 Athens, Greece
}

\author{
Article history: \\ Received: 19 February 2017 \\ Received in revised form: \\ 25 March 2017 \\ Accepted: 25 March 2017 \\ Available Online: \\ 28 March 2017 \\ Keywords: \\ Consumer behavior \\ Organic products \\ Health issues \\ Safety \\ Nutritive value \\ Dissemination \\ DOI: \\ http://doi.org/10.26656/ \\ fr.2017.2.009
}

\begin{abstract}
The objective of the present study was to investigate the awareness, knowledge and consumers' behavior towards organic vegetables in Cyprus. For this study, a deliberate sampling technique was used in order to identify a sample group of 180 consumers over the age of 18 years who indented or made purchases from 1) grocery stores; 2) street market; and, 3) supermarkets. A questionnaire was used for data collection across the country. Descriptive statistics were used for data analysis. The results revealed that $99 \%$ of Cypriot consumers were aware of organic vegetables but only $69 \%$ and $49 \%$ of them consume or have knowledge of organically cultivated vegetables, respectively. According to Cypriots, organic vegetables are healthier, fresher and tastier than conventional vegetables. On the other hand, there appears to be a lack of knowledge about the stipulations of organic farming but consumers show great willingness not only to get properly informed via different means but to pay higher for organic vegetables. Concluding, consumers, organic farm holders and distributors should work together to create well-established strategies what will provide a better place in the market for organic products.
\end{abstract}

\section{Introduction}

Nowadays, consumers are concerned about health-related issues as well as nutrition. They have changed their dietary preferences as they started to look for fresh, nutritious and safe food; that is, without additives and preservatives. Food quality and safety are crucial for purchasing a product as an increased number of outbreaks associated with fresh produce have been observed in the last few years (EFSA, 2013). Therefore, more and more consumers turn to organic foods for a safer, healthier and environmentally friendly option (Shepherd et al., 2005; Kongsom and Kongsom, 2016).

Organic foods are produced according to organic farming/agriculture and good farming practices (GAP) where products are produced/grown with natural processes and without the use of chemical synthetic fertilizers and pesticides (Bourn and Prescott, 2002). These practices often meet consumer's expectations for less processed and safer food. The demand for organically grown food has been increased in the last twenty-five years (Williams and Hammitt, 2001). Although the consumption of organically grown food is popular in developed countries, most of the organic farming areas are located in developing countries where awareness for organic food has also increased (Chakrabarti, 2010).
In Europe, organic food market has been doubled between 2004 and 2012; however, this part of the food market is still very small compared with conventional food market (Bryla, 2015; Food Drink Europe, 2015). In Cyprus, organic farming started in 1987 and by 2010 the number of organic farmers has reached up to 732. In 2010, the organic farming in Cyprus was the $2.9 \%$ of the total cultivated area for fruits and vegetables production. According to the Cypriot Ministry of Agriculture, by the next five years organic farming cultivated area is expected to reach $5 \%$ of the total cultivated area (Piggouras, 2015). The increased demand for organically grown products, consumer's fears for chemical residues in fresh produce and the increased awareness for environmentally friendly procedures are some of the main reasons for the increased organic farming areas in Cyprus (Piggouras, 2015).

A number of studies have examined the nutritional value of organic and conventional fruits and vegetables; however, it is not clear that organic and conventional foods differ in nutrient composition. For example, when Ren et al. (2017) assessed the antioxidant activity and the phenolic content of organically and conventionally grown onions, it was found that organically grown onions presented greater total phenolic and total flavonoid content as well as greater antioxidant activity. Moreover, Anon. 
(2000) found similar levels of vitamin C and carotene in organically grown and conventional green beans, tomatoes, peppers and silver beet. In addition to these findings, the levels of minerals were higher in organically grown vegetables. On the other hand, D' Evoli et al. (2016) observed no difference in phenolic acids, minerals and trace elements between conventional, organic and biodynamic cultivations of tomatoes.

Researchers in many countries studied consumer's behavior and knowledge on organic products. For example, Bryla (2016) found out that Polish consumers perceived that organic food is healthier, tastier and environmentally friendly; yet more expensive than conventional food. This may lead to the perception that organic food targets more towards the wealth rather than the ordinary (middle class) people. In another study that took place in Thailand, researchers observed that the main reason for buying organic food was safety; a very small part of the consumers knew how to identify food safety and organic food logos (Kongsom and Kongsom, 2016). In order to understand consumer's behavior regarding organic food we cannot only rely on research. At the end of the day, it is consumers who are the decision makers and determine the market. Consumers may be concerned about their health and nutrition; however, the lack of knowledge regarding organic food results in the need for proper consumer education (Tsakiridou et al., 2008). In many countries of the Mediterranean region such as Cyprus vegetables play an important part for a healthy and balanced diet (Mediterranean diet) but the data on consumer's behavior and knowledge on organic vegetables is lacking.

Thus, the main objective and priority of this study was to investigate the behavior and attitude of Cypriot consumers towards organically grown vegetables as well as their perception towards organic farmers.

\section{Materials and methods}

The researchers' tool was a questionnaire concerning organic fresh production designed by the authors based on a literature review and then modified for the Cypriot consumers. A preliminary survey for data collection was observed in order to identify missing info needed for accurate data collection, and the questionnaire was revised appropriately.

The questionnaire was written in Greek and included 35 questions. For the purpose of the study, a survey on 180 Cypriot consumers living in 4 different districts in Cyprus (Nicosia, Limassol, Larnaca and Pafos), aged over 18 years and responsible for ordinary domestic shopping (consumers straight from markets, householders, farmers, business holders, academics, students, civil servants etc.) was conducted.

Prior to filling the form, consumers were given a short guidance for the correct filling of the form, and all respondents were encouraged to read the short paragraph concerning organic farming at the beginning of the leaflet. Each question has a catalogue/range of options and, the respondents had the opportunity to fill their own answer whenever needed.

The questions were divided in 6 groups. The first group contained questions that serve the demographic profile of the survey (age, sex and educational status). Then, there was a group of questions focusing on how familiar the respondents are to organic products. The next part of the questions referred to the financial aspect, to the willingness of the consumer to pay for organic products, but also focused on how much consumers tend to spend for food in general (vegetables, meat, dairy etc.). The fourth group of questions was about the consumers' buying behavior and their opinion about organic and conventional producers/markets. After that, a set of questions followed, concerning the way consumers wish to be informed/ of organic products. The final part took into account nutritional facts of organic products and the extent to which consumers are familiar with them, as well as the level of awareness towards the health aspects of these products.

During the study, both random and face-toface interview methods were used for the data collection, as well as structured questionnaires with both open-ended and closed-ended questions. The purposive sampling technique was used to approach consumers of different sex, age and education status and willingness to answer the question. The data was analyzed using descriptive statistics; percentage, mean and standard error as well as regression analysis, when needed. The statistical analysis was performed using with SPSS 22.0 package for Windows.

\section{Results}

Given the fact that respondents were chosen randomly, the results could be generalized as a tendency for Cypriots consumers. Nevertheless, since the purpose of the study was to provide indications about consumer behavior towards organic vegetables, rather than statistically describe the population, the sampling procedure could be considered sufficient to achieve this goal. A total of 180 questionnaires were collected, with the detailed respondents' socio- 
demographics were tabulated as shown in Table 1. Cyprus is a small country, counting not more than 850,000 habitants. The sample consisted of $48 \%$ men and 52\% women, percentages which are in sharp accordance with the general population of Cyprus (48.58\% men and 51.42\% women, according to Statistical Service of the Republic of Cyprus (CYSTAT, 2013). Among the respondents, 43\% have a university degree of any level (in Cyprus the corresponding percentage is according to CYSTAT is $28 \%$ ), while only $3 \%$ is of primary educational status. The age of the study subjects ranges from 18 to $>51$, and the figures for each age group are similar to general population.

Table 1. Demographic characteristics of responders

\begin{tabular}{lcc}
\multicolumn{3}{c}{$(\mathrm{n}=180)}$. \\
\hline Characteristics & Factors & Percentage \\
\hline Gender & Male & $48 \%$ \\
\multirow{3}{*}{ Age } & Female & $52 \%$ \\
& $18-25$ years & $24 \%$ \\
& $26-35$ years & $22 \%$ \\
& $36-50$ years & $32 \%$ \\
Educational status & $>51$ years & $22 \%$ \\
& Primary education & $3 \%$ \\
& Secondary education & $54 \%$ \\
& University degree & $28 \%$ \\
& Postgraduatedegree & $15 \%$ \\
& (Master) & \\
& Postgraduatedegree & $0 \%$ \\
& (Doctorate) & \\
\hline
\end{tabular}

Table 2. Knowledge about organic products.

\begin{tabular}{|c|c|c|c|}
\hline Characteristics & & Responses & \\
\hline $\begin{array}{l}\text { Knowledge } \\
\text { about organic }\end{array}$ & Yes & No & \\
\hline vegetables & $99 \%$ & $1 \%$ & \\
\hline $\begin{array}{l}\text { Knowledge of } \\
\text { selling points/ }\end{array}$ & Supermarket & Streetmarket & $\begin{array}{c}\text { Grocery } \\
\text { store }\end{array}$ \\
\hline availability & $62 \%$ & $18 \%$ & $20 \%$ \\
\hline $\begin{array}{l}\text { Distinction } \\
\text { of organic }\end{array}$ & Yes & No & $\begin{array}{l}\text { Do not } \\
\text { know }\end{array}$ \\
\hline $\begin{array}{l}\text { vegetables at } \\
\text { selling points }\end{array}$ & $72 \%$ & $7 \%$ & $21 \%$ \\
\hline $\begin{array}{l}\text { Knowledge } \\
\text { of organically }\end{array}$ & Yes & No & \\
\hline $\begin{array}{l}\text { cultivated } \\
\text { vegetables }\end{array}$ & $49 \%$ & $51 \%$ & \\
\hline Consumption & Yes & No & \\
\hline vegetables & $69 \%$ & $31 \%$ & \\
\hline
\end{tabular}

As shown in Table 2, almost all respondents $(99 \%)$ knew about organic vegetables and their existence. That of course does not mean they all have purchased or consumed organic vegetable.
$69 \%$ of the respondents have at least once consumed organic vegetables. According to Cypriot consumers, organic vegetables are sold at super markets $(72 \%)$, at grocery stores $(20 \%)$ and at street (open) market (18\%). According to our survey, in Cyprus, organic vegetables are clearly distinct from conventional or other kind of vegetables, whilst $72 \%$ of the subject did mention that fact. Nevertheless, 1 out of 5 people do not know if there is a clear classification. In Figure 1 , consumers of organic vegetables indicated the kind of organic vegetable they consume. Tomato is the dominant vegetable (34\%) followed by cucumber (24\%) and lettuce (21\%). Pepper and eggplant are next (14\% and $7 \%$ respectively), while there are no other submissions made from consumers. At this stage, it should be mentioned that potato is the most widely-grown vegetable crop in Cyprus, followed by tomato especially in greenhouse and intensively cultivated enterprises i.e. hydroponics.

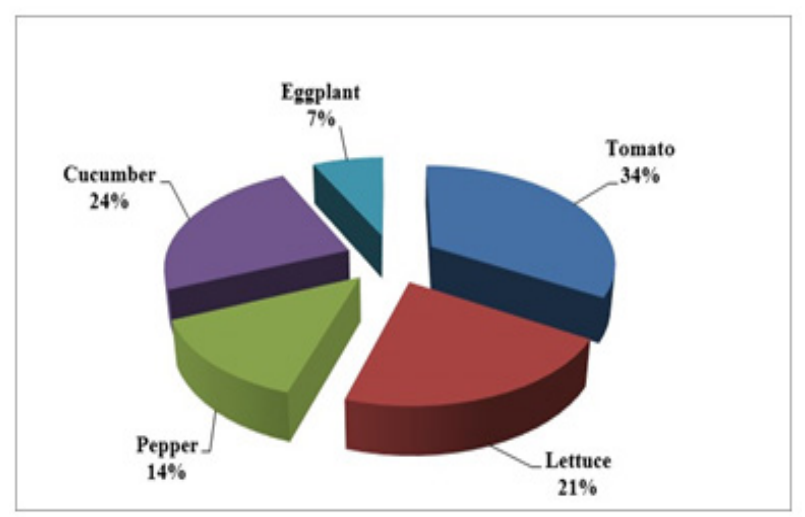

Figure 1. Organic vegetables preferred by consumers.

As it was mentioned that $69 \%$ of the subjects declared consuming organic vegetables, but there is a great variability concerning the frequency of buying/ consuming (Table 3). Only $12 \%$ of the organic vegetables consumers are frequent buyers. There are $43 \%$ of occasional consumers and a great percentage of $46 \%$ of consumers that purchase such vegetables rather seldom. The buying motives vary among consumers, and they are mainly determined by "healthy" parameters (41\%), followed by parameters of "flavor" (25\%) and "freshness" (15\%). The price of organic vegetables has the lower buying motive as $13 \%$ of consumers evaluated them as "high price" and $65 \%$ evaluated organic vegetables as "higher price than conventional". 
Table 3. Organic vegetable consumers' behavior.

\begin{tabular}{llllll}
\hline Characteristics & \multicolumn{5}{c}{ Responses } \\
\hline $\begin{array}{lllll}\text { Frequency of } \\
\text { buying }\end{array}$ & Frequently & Occasionally & Rarely & & \\
& $12 \%$ & $43 \%$ & $46 \%$ & & \\
Buying motives & Flavor & Freshness & Healthy & Price & Neverbought \\
& $25 \%$ & $15 \%$ & $41 \%$ & $1 \%$ & $18 \%$ \\
Price evaluation & Affordable & $\begin{array}{l}\text { Higher than } \\
\text { conventional }\end{array}$ & High & & \\
& $22 \%$ & $65 \%$ & $13 \%$ & & \\
& & & & \\
\hline
\end{tabular}

Due to the well-recognized quality and organoleptic characteristics of organic vegetables (as indicated in Table 3), 77\% of the respondents are willing to pay higher price to consume organic vegetables (Figure2A). Majority (56\%) of the consumers are willing to pay up to $25 \%$ of the current price for organic vegetables consumption, whereas the increased prices for organic vegetables should not be more than1.5-fold than the current prices, as consumers are not willing to purchase them in that case (Figure 2B).

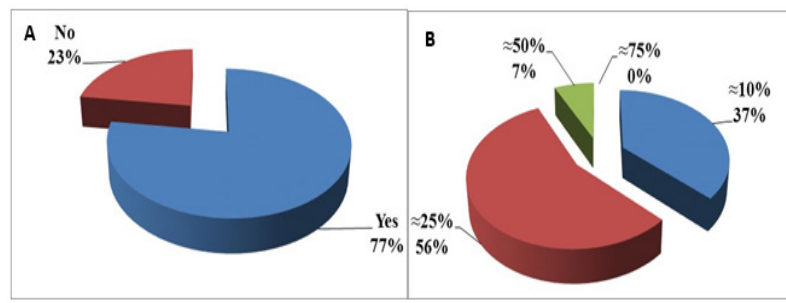

Figure 2. Willingness of paying A) higher price and B) the value of the higher prices that respondents are willing to pay for organic vegetables.

Most of the buyers are spending 25-50€ monthly for food, with greater expenses on meat, followed by diary, vegetables and finally bakery (Figure 3). Quite interestingly, a considerable percentage of consumers (23.3\%) are spending $100 €$ for meat on a monthly basis. Examining the food monthly expenses of respondents according to their age and behavior, it was found that consumers $<35$ years old spent almost half on vegetables, $31 \%$ less on dairy products and up to $33 \%$ on bakery compared with middle aged

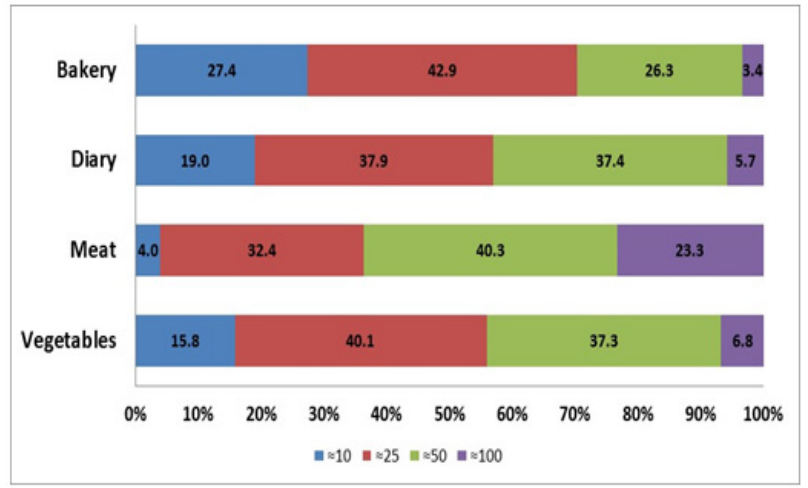

Figure 3. How much money consumers usually spend, per month, for bakery, diary, meat and vegetables.

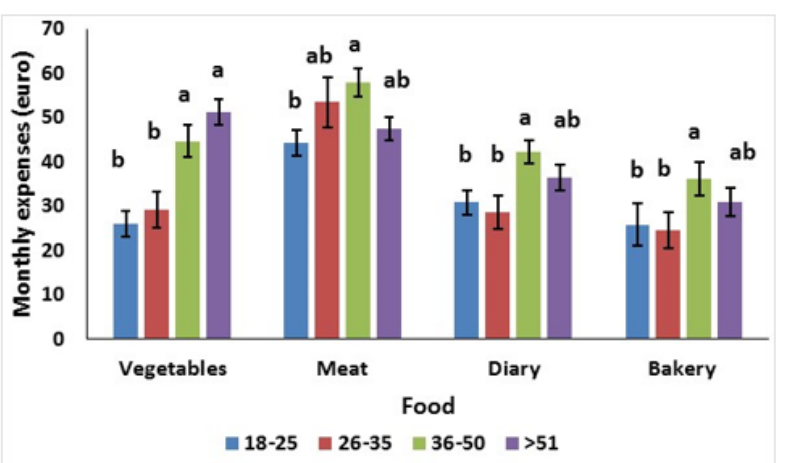

Figure 4. Food monthly expenses of respondents according to their age and behavior for bakery, diary, meat and vegetables. Mean values $( \pm \mathrm{SE})$ followed by the same letter in each food category are not significantly different, $P<0.05$.

consumers (36-50 years old) as presented in Figure 4. Regression analysis among consumers age levels and monthly expenses in different food types revealed a significant positive correlation as age was increased from 18 to $>51$ years old for vegetable consumption $(\mathrm{P}<0.0001)$, dairy consumption $(\mathrm{P}=0.0363)$ and bakery $(\mathrm{P}=0.0395)$, whereas meat consumption did not follow any correlation with consumers age $(\mathrm{P}=$ 0.3973).

Respondents mainly consume conventional vegetables (up to $44 \%$ ) and $28 \%$ of open field vegetables production with a noticeable consumption $(12 \%)$ of organic vegetables as well as individual production (13\%) (Table 4). Almost half of the respondents believe that organic vegetables are as safe as the conventional ones, and a $75 \%$ of respondents mentioned that organic farming does not burden the environment. Almost one out of four of the respondents are not aware for the organic farming effects on the environment, indicating a considerable gap of knowledge on the part of the consumers. Regarding the consumer's trust to farmers for producing vegetables of high quality and to traders for trading vegetables of high quality there is a considerable percentage (39\% and $46 \%$ respectively) that concern consumer's attitude, and several tools for consumer's trust improvement need to be explored.

Therefore, dissemination is of high importance in order to improve consumer's knowledge and awareness. Dissemination is a powerful tool on consumer's behavior attitude but in order to succeed, the willingness of the individuals is necessary. For this task, $88 \%$ of the respondents expressed willingness to be informed about organic farming, but they were not really ready to be a member of organic vegetable group (Table 5). Different target groups might prefer different ways of being informed about organic farming (Figure 5). The majority $(32 \%)$ of the respondents preferred TV/Radio as dissemination tool, followed by internet $(25 \%)$, 
Table 4. Attitude towards organic technique and producers/markets.

\begin{tabular}{|c|c|c|c|c|c|}
\hline Characteristics & & & Responses & & \\
\hline \multirow[t]{2}{*}{ Kind of vegetables consumed } & Organic & Conventional & $\begin{array}{c}\text { Integrated } \\
\text { management }\end{array}$ & $\begin{array}{c}\text { Own } \\
\text { production }\end{array}$ & Open-field \\
\hline & $12 \%$ & $44 \%$ & $4 \%$ & $13 \%$ & $28 \%$ \\
\hline \multirow{2}{*}{$\begin{array}{l}\text { Conventional vegetables as safe as } \\
\text { organic }\end{array}$} & Yes & No & & & \\
\hline & $51 \%$ & $49 \%$ & & & \\
\hline \multirow[t]{2}{*}{ Organic farming burdens environment } & Yes & No & Don’t know & & \\
\hline & $2 \%$ & $75 \%$ & $23 \%$ & & \\
\hline \multirow{2}{*}{$\begin{array}{l}\text { Trust farmers for producing } \\
\text { vegetables of high quality }\end{array}$} & Yes & Frequently & Occasionally & Rarely & No \\
\hline & $11 \%$ & $34 \%$ & $39 \%$ & $4 \%$ & $12 \%$ \\
\hline \multirow{2}{*}{$\begin{array}{l}\text { Trust traders for trading vegetables of } \\
\text { high quality }\end{array}$} & Yes & Frequently & Occasionally & Rarely & No \\
\hline & $1 \%$ & $19 \%$ & $46 \%$ & $21 \%$ & $12 \%$ \\
\hline
\end{tabular}

Table 5. Dissemination and networking in organic vegetable groups.

\begin{tabular}{lcc}
\hline Characteristics & \multicolumn{2}{c}{ Responses } \\
\hline Willingness to get informed & Yes & No \\
for organic farming & $88 \%$ & $12 \%$ \\
\hline Willingness to be a member & Yes & No \\
of organic vegetable group & $34 \%$ & $66 \%$ \\
\hline
\end{tabular}

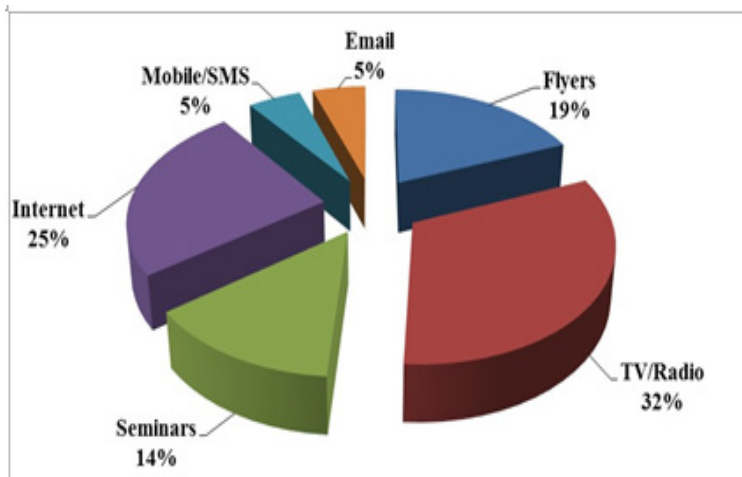

Figure 5. Preferable ways of being informed for organic farming.

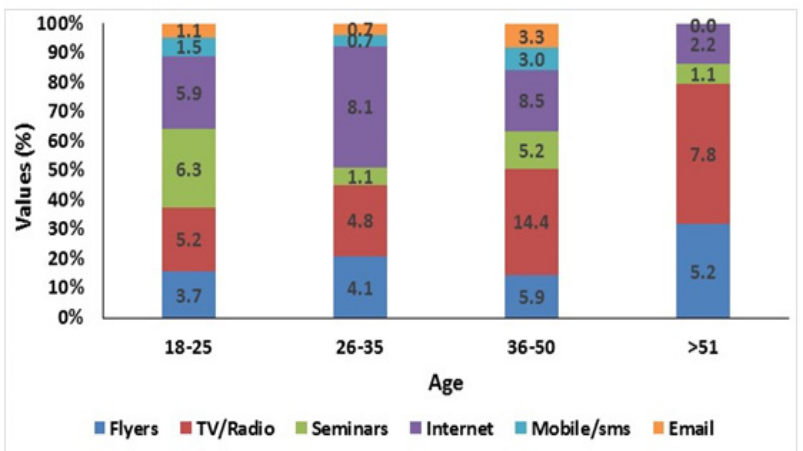

Figure 6. Percentage distribution of dissemination means for different age consumers for organic farming.

flyers (19\%), seminars (14\%), mobile/short message service -sms (5\%) and email (5\%). Therefore, TV/ Radio seemed to be the most efficient dissemination tool for organic farming, with higher acceptance to respondents $>51$ years old (Figure 6). Mobile/sms and email are preferred by respondents $<50$ years old whereas internet is the major dissemination tool for 26-35 years old consumers. More traditional tools (TV/Radio, flyers) are preferred by elder consumers, whereas modern/electronic approaches (seminar, email, mobile/sms and internet) are appropriate for the younger consumers.

The last part of the questionnaire related to the nutritional facts of organic products and in what degree consumers are familiar with them and the level of awareness towards the health aspects of these products. The majority (more than $84 \%$ ) of the respondents were aware that vegetables have medicinal properties. Therefore, the consumer's estimation on vegetable nutrition content is presented in Table 6, which is partly disappointing, according to the consumers answers. In details, only $41 \%$ of the answers were absolutely correct, indicating that water content in vegetables is more than $80 \%$, while a considerable percentage $(43 \%)$ of the respondents believe that vegetables contain $50 \%$ of water, which is true only for very few species i.e. potato. $16 \%$ of the answers related to vegetables water content are wrong. Similar misleading answers were marked for the carbohydrates and proteins content of vegetables, whereas only $75 \%$ and $49 \%$ respectively of the answers were correct. Respondents correctively marked that vegetables have $\sim 100-150$ calories per $100 \mathrm{~g}$ of fresh produce.

Table 6. Consumers' estimation of vegetable nutrition facts

\begin{tabular}{lccccc}
\hline Characteristic & \multicolumn{5}{c}{ Responses } \\
\hline Water & $\approx 1 \%$ & $\approx 15 \%$ & $\approx 50 \%$ & $>80 \%$ & \\
& $1 \%$ & $15 \%$ & $43 \%$ & $41 \%$ & \\
\hline Carbohydrates & $1-3 \%$ & $4-25 \%$ & $26-50 \%$ & $>50 \%$ & \\
& $26 \%$ & $49 \%$ & $21 \%$ & $4 \%$ & \\
\hline \multirow{2}{*}{ Proteins } & $1-25 \%$ & $26-50 \%$ & $\approx 80 \%$ & $>80 \%$ & \\
& $49 \%$ & $34 \%$ & $14 \%$ & $3 \%$ & \\
\hline Caloriesper & $\approx 100$ & $\approx 150$ & $\approx 200$ & $\approx 250$ & $\approx 500$ \\
100 g & $69 \%$ & $28 \%$ & $1 \%$ & $2 \%$ & $0 \%$ \\
\hline
\end{tabular}




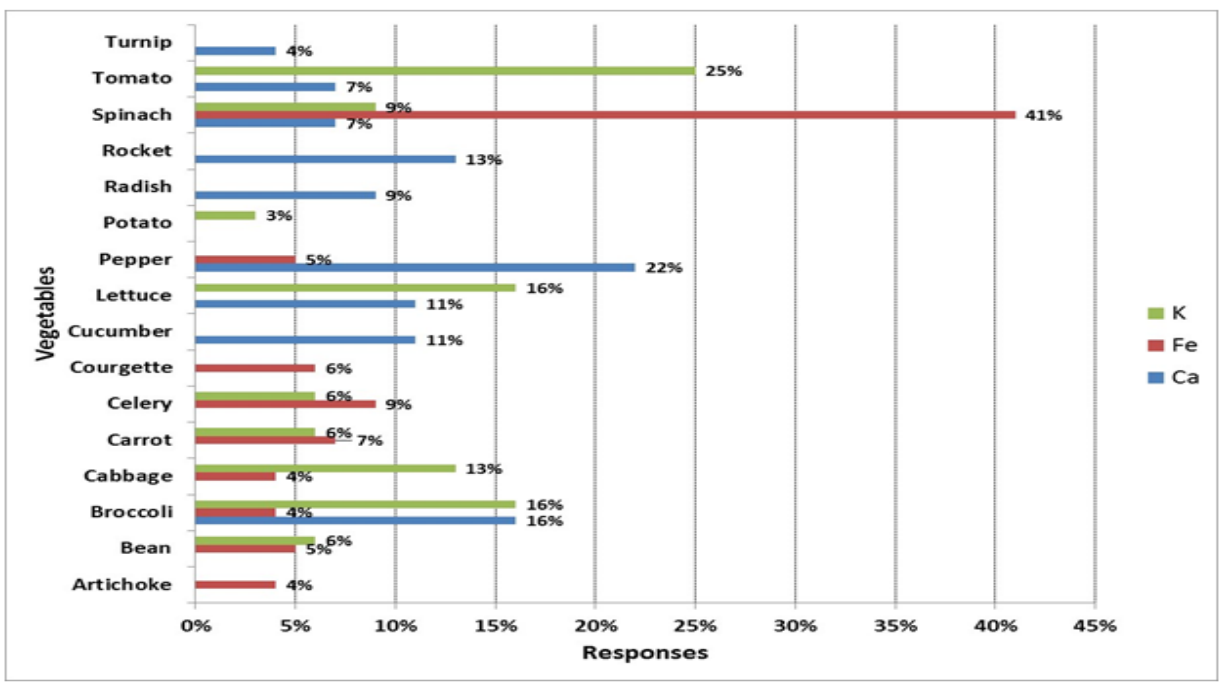

Figure 7. Percentage responses regarding the mineral (K, Fe, Ca) content of vegetables.

When respondents were asked if they believe that vegetables contain minerals, only $38 \%$ were aware of the nutritive value of vegetables and the $56 \%$ of respondents marked as "I do not know". Consumers were asked to identify vegetables they believe that are of high mineral content, thus enriched nutritional status, and more specifically to potassium (K), iron $(\mathrm{Fe})$ and calcium $(\mathrm{Ca})$ content (Figure 7). According to the answers collected, most of the responses (41\%) selected spinach with great $\mathrm{Fe}$ content, followed by celery and carrots. Respondents thought that tomatoes $(25 \%)$ were rich in $\mathrm{K}$, followed by lettuce and broccoli. Regarding $\mathrm{Ca}$ content in vegetables, respondents marked pepper $(22 \%)$ rich in $\mathrm{Ca}$, followed by lettuce and broccoli.

Consumers were aware for the presence of vitamins in vegetables, as $65 \%$ of the respondents showed a positive response, and $34 \%$ of the respondents did not (Figure 8). The response for the vitamins that are present in vegetables are vitamins C, A, B, E, D and K with 37\%, 20\%, 20\%, 12\%, 9\% and $2 \%$, respectively.

Table 7 demonstrates the awareness of facts about organic vegetables related to human health. Therefore, most of the respondents (up to $72 \%$ ) do not know that organic vegetables contain up to $60 \%$ more antioxidants than conventional ones. Moreover, $45 \%$ of the respondents knew that conventional vegetables contained up to 4 times more pesticide residues than organic, while one of every third respondent does know that when consuming organic vegetables, the risk of cancer of stomach is lower.
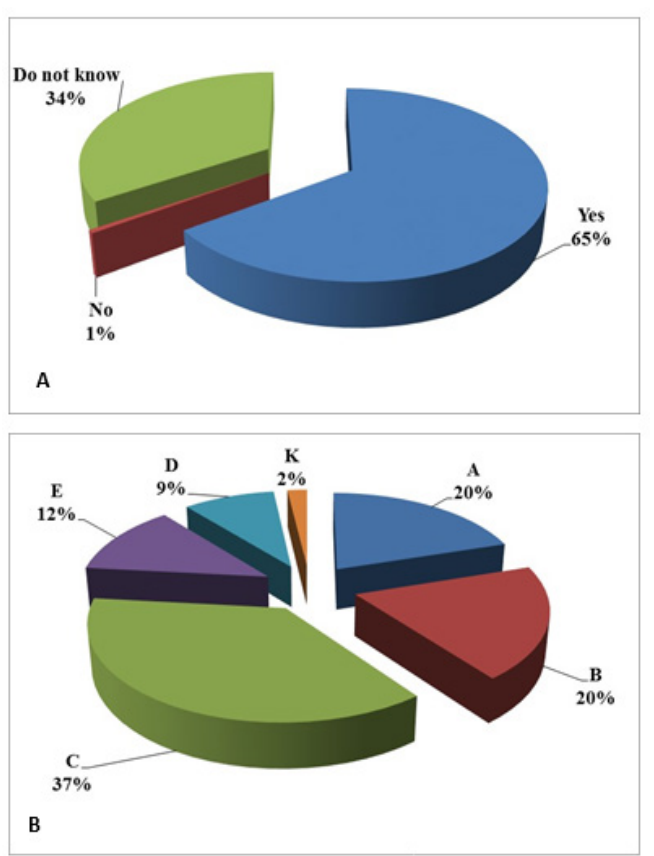

Figure 8. Consumer's awareness for the (A) presence and (B) kind of vitamins in vegetables grown organically.

Table 7. Awareness of facts about organic vegetables related to human health.

\begin{tabular}{lcc}
\hline Characteristics & \multicolumn{2}{c}{ Responses } \\
\hline Do you know if........ & Yes & No \\
\hline $\begin{array}{l}\text { Organic vegetables contain up to 60\% more } \\
\text { antioxidants than conventional }\end{array}$ & $28 \%$ & $73 \%$ \\
$\begin{array}{l}\text { Conventional vegetables contain up to } 4 \\
\text { times more pesticide residues than organic }\end{array}$ & $45 \%$ & $55 \%$ \\
$\begin{array}{l}\text { Organic vegetables contain up to 50\% } \\
\text { less toxic substances (heavy metals) than } \\
\text { conventional }\end{array}$ & $40 \%$ & $60 \%$ \\
$\begin{array}{l}\text { Consuming organic vegetables the risk of } \\
\text { cancer of stomach is lower }\end{array}$ & $33 \%$ & $67 \%$ \\
\hline
\end{tabular}




\section{Discussion}

Food consumption patterns are expeditiously changing and consumers are concerned about food and health related nutritional value issues. Therefore, increasing interest and awareness regarding the health implications of food provides evidence for safe food consumption, which includes organic vegetables (Schleenbecker and Hamm, 2013). Due to environmental sensitivity of consumers, environmentally friendly products are gaining acceptance among consumers, who are increasingly aware of their health and the environment protection. The topic of the absence of chemical residues or the avoidance of pesticide application was examined in detail by Tsakiridou et al. (2008). They found that, from written interviews with 660 consumers, Greek consumers expect organic products to be free from chemical residues. This aspect is also addressed by Cranfield et al. (2009) and Stolz et al. (2009).

Given the fact that each country has a different perspective/attitude towards organic products and food consumption in general, consumer's behavior surveys are of great importance in order to obtain information about current tendencies and policies in the market. On top of that, organic vegetable producers, traders and distributors could use these valuable results to develop and promote organic vegetables, according to public demands.

The present study explored the behavior of Cypriot consumers towards organic vegetables. What is noticeable about Cyprus is the fact that although the $99 \%$ of the subject knows about organic vegetables, one out of two vegetable consumers believes that organic farming burdens the environment. That means that although (organic or not) vegetable consumers recognize organic products as healthier, tastier and fresher than conventional, there is still lack of knowledge regarding the stipulations of organic farming. A study in Netherlands reported that consumers perceive that organically grown vegetables are healthier, more nutritious and less contaminated with synthetic pesticide residues, harmful microorganisms and mycotoxins than conventionally grown vegetables (Hoefkens et al., 2009). These findings can be supported, in part, by Magnusson et al. (2001) who interviewed 1154 Swedish consumers using a written questionnaire. They also found that taste and health are the two most important purchase criteria for organic products, further important aspects being long shelf-life and the core quality of the product. Zanoli and Naspetti (2002), who performed an exploratory laddering approach with 60 consumers in Italy, identified that consumers associate taste and health with organic products.

The factors that Cypriots use to distinguish organic vegetables from conventional come in high accordance with studies from Germany and Poland (Gottschalk and Leistner, 2013; Bryla, 2016). The latter indicated that consumers are willing to pay higher for organic food (17.4\% higher). In Cyprus, this percentage rise to $25 \%$. According to a survey that took place in Denmark, consumers with positive attitude towards organic products were more willing to pay more for organic food than consumers with less positive attitude (Lund et al., 2013). Those findings were reported by other researchers (Gil et al., 2000; Bean and Sharp, 2011). Hoefkens et al. (2009) reported that the perception for organic products was higher in consumers who bought organic products more often. In the present study, more than $80 \%$ of Cypriots that participated in the survey were positive for spending more for organic products. However, according to Feldmann and Hamm (2015), willingness-to pay values are most likely biased and overestimated, noticing that when stating that would pay higher that does not take place during purchase.

The willingness of the Cypriot consumers to pay more comes along with the readiness to get informed about organic farming, probably due to the fact that only an average of one out of three interrogates is familiar with facts associating organic vegetables to human health, according to Table 7 . That means that there is a severe lack of information. Providing a clear picture to the public about organic farming, organic products and safe foods may encourage consumers to purchase organic vegetables more often. Emphasis should be given to the production line of organic vegetables that are grown without the use of pesticides and contain fewer residues, praising the nutritional value of the final product.

Consumers in Thailand, when surveyed, have reported that price and convenience are the two main factors that they take under consideration before selecting and purchasing any organic product (Kongsom and Kongsom, 2016). In another study by Lee and Yun (2015) it has been stated that the main reasons that consumers purchase organic food are the nutritional content of the product and the ecological impact of that product. When interviewing 23 organic consumers qualitatively in China, Sirieix et al. (2011) were also able to identify health as an important purchase criterion. As it has been surveyed for other countries (Fotopoulos and Krystallis, 2002; RoitnerSchobesberger et al., 2008; Bryla, 2016) high price of organic vegetables in Cyprus is the major barrier for consumers and this will generate less repeat purchase 
as well (Marian et al., 2014). Another obstacle is the limited amounts of available organic vegetables in market, due to the restricted organic farms in Cyprus. Besides that, $72 \%$ of the respondents can find and distinguish organic vegetables from conventional in the purchase areas but only $44 \%$ of the public consumes mostly conventional vegetables. Consumers may consider the health benefits of organic vegetables, but pragmatic shoppers do purchase according to the availability, visibility of the products and the price of each product (Schleenbecker and Hamm, 2013).

Consumer's behavior surveys and conclusions derived on such studies provide valuable information for the consumer's perspectives towards organic products. Additionally, manufacturers and distributors of organic products can use such information to plan the production and distribution of organic products in a more appropriate way, which meets consumers' demands more directly, leading to the development of organic farming in the country. Consumers should have clear information about organic farming. Providing consumers with clear information about organic products and the difference between organic products and safe foods, may encourage consumers to purchase more organic products.

\section{References}

Anonymous. (2000). Organic food is far more nutritious. Australia: National Association of Sustainable Agriculture Australia (NASAA).

Bean, M. and Sharp, J.S. (2011). Profiling alternative food system supporters: The personal and social basis of local and organic food support. Renewable Agriculture and Food Systems, 26(03), 243-254.

Bourn, D. and Prescott, J. (2002). A comparison of the nutritional value, sensory qualities and food safety of organically and conventionally produced foods. Critical Reviews in Food Science and Nutrition, 42(1), 1-34.

Bryła, P. (2015). The development of organic food market as an element of sustainable development concept implementation. Problemy Ekorozwoju, 10, 79-88.

Bryla, P. (2016). Organic food consumption in Poland: Motives and barriers. Appetite, 105, 737-746.

Chakrabarti, S. (2010). Factors influencing organic food purchase in India-expert survey insights. British Food Journal, 112(8), 902-915.

Cranfield, J., Deaton, B. J. and Shellikeri, S. (2009). Evaluating consumer preferences for organic food production standards. Canadian Journal of Agricultural Economics, 57, 99-117.

CYSTAT. (2013). Statistical Service of the Republic of Cyprus. Retrieved from CYSTAT website: http:// www.mof.gov.cy/mof/cystat/ statistics.nsf/index_en/ index_en?OpenDocument).
D’ Evoli, L., Lucarini, M., delPulgar, J.S., Aguzzi, A., Gabrielli, P., Gambelli, L. and Lombardi-Boccia, G. (2016). Phenolic acids content and nutritional quality of convention, organic and biodynamic cultivations of the tomato CXD271BIO breeding line (Solanum lycopersicum L.). Food and Nutrition Sciences, 7, 1112-1121.

European Food Safety Authority (EFSA). (2013). Panel on Biological Hazards (BIOHAZ) Panel; Scientific opinion on the risk posed by pathogens in food of non-animal origin. Part 1 (outbreak data analysis and risk ranking of food/pathogen combinations). EFSA Journal, 11(1), 3025.

Feldmann, C. and Hamm, U. (2015). Consumers' perception and preferences for local food: A review. Food Quality and Preference, 40, 152-164.

Food Drink Europe. 2015. Data and trends. European food and drink industry 2014-2015. Retrieved on February 2, 2017 from Food Drink Europe website: http://www. fooddrinkeurope.eu/uploads/publications_documents/ Data_and_Trends_2014-20151.pdf/.

Fotopoulos, C. and Krystallis, A. (2002). Organic product avoidance. Reasons for rejection and potential buyers' identification in a countrywide survey. British Food Journal, 104, 233-260.

Gil, J.M., Gracia, A. and Sanchez, M. (2000). Market segmentation and willingness to pay for organic products in Spain. The International Food and Agribusiness Management Review, 3(2), 207-226.

Gottschalk, I. and Leistner, T. (2013). Consumer reactions to the availability of organic food in discount supermarkets. International Journal of Consumer Studies, 37, 136-142.

Hoefkens, C., Verbeke, W., Aertsens, J., Mondelaers, K. and Van Camp, J. (2009). The nutritional and toxicological value of organic vegetables: Consumer perception versus scientific evidence. British Food Journal, 111(10), 1062-1077.

Kongsom, W. and Kongsom, C. (2016). Consumer Behavior and Knowledge on Organic Products in Thailand. International Scholarly and Scientific Research and Innovation, 10(8), 2534-2538.

Lee, H.J. and Yun, Z.S. (2015). Consumers' perceptions of organic food attributes and cognitive and affective attitudes as determinants of their purchase intentions toward organic food. Food Quality and Preference, 39, 259-267.

Lund, T.B., Andersen, L.M. and O'Doherty Jensen, K. (2013). The emergence of diverse organic consumers: Does a mature market undermine the search for alternative products?. Sociologia Ruralis, 53(4), 454478.

Magnusson, M.K., Arvola, A., Hursti, U.-K., Eberg, L. and Sjoden, P.-O. (2001). Attitudes towards organic foods among Swedish consumers. British Food Journal, 103, 209-227.

Marian, L., Chrysochou, P., Krystallis, A. and Thøgersen, J. (2014). The role of price as a product attribute in the organic food context: An exploration based on actual purchase data. Food Quality and Preference, 37, 5260. 
Piggouras, L. (2015). Cyprus Organic Farmers Associations. Retrieved on January 18, 2017 from website:http://biocyprus.eu/en/.

Ren, F., Reilly, K., Gaffney, M., Kerry, J.P., Hossain, M. and Rai, D.K. (2017). Evaluation of polyphenolic content and antioxidant activity in two onion varieties grown under organic and conventional production systems. Journal of the Science of Food and Agriculture. DOI $10.1002 /$ jsfa. 8138 .

Roitner-Schobesberger, B., Darnhofer, I., Somsook, S. and Vogl, C.R. (2008). Consumer perceptions of organic food in Bangkok, Thailand. Food Policy, 33, 112-121.

Schleenbecker, R. and Hamm, U. (2013). Consumers' perception of organic product characteristics. A review. Appetite, 71, 420-429.

Shepherd, R., Magnusson, M. and Sjoden, P-O. (2005). Determinants of consumers' behavior related to organic foods. AMBIO A Journal of the Human Environment, 34(4-5), 352-359.

Sirieix, L., Kledal, P.R. and Sulitang, T. (2011). Organic food consumers' trade-offs between local or imported, conventional or organic products. A qualitative study in Shanghai. International Journal of Consumer Studies, 35, 670-678.

Stolz, H., Bodini, A., Stolze, M., Hamm, U. and Richter, T. (2009). A synthesis of qualitative studies about consumers' perception and assessment of individual quality. Berichte óber Landwirtschaft, 87, 153-182.

Tsakiridou, E., Boutsouki, Ch., Zotos, Y. and Mattas, K. (2008). Attitudes and behavior towards organic products. An exploratory study. International Journal of Retail and Distribution Management, 36, 158-175.

Williams, P.R. and Hammitt, J.K. (2001). Perceived risks of conventional and organic produce: pesticides, pathogens, and natural toxins. Risk Analysis, 21(2), 319-330.

Zanoli, R. and Naspetti, S. (2002). Consumer motivations in the purchase of organic food. A means-end approach. British Food Journal, 104, 643-653. 